Article

\title{
Oxidative coupling of alcohols and amines to an imine over Mg-Al acid-base bifunctional oxide catalysts
}

\author{
Jinling Song a, Guiyang Yu a, Xi Li a, Xuwei Yang a, Wenxiang Zhang a,*, Wenfu Yan b, Gang Liu a,\# \\ a Key Laboratory of Surface and Interface Chemistry of Jilin Province, College of Chemistry, Jilin University, Changchun 130012, Jilin, China \\ b State Key Laboratory of Inorganic Synthesis and Preparative Chemistry, College of Chemistry, Jilin University, Changchun 130012, Jilin, China
}

\section{A R T I C L E I N F O}

\section{Article history:}

Received 13 November 2017

Accepted 25 December 2017

Published 5 February 2018

\section{Keywords:}

Oxidative coupling

Imine synthesis

Alcohol oxidation

Mg-Al mixed oxides

Acid-base catalysis

\begin{abstract}
A B S T R A C T
A series of Mg-Al mixed oxide catalysts are prepared and introduced as efficient irreducible catalysts for the oxidative coupling of alcohols and amines to imine. The structure and surface properties of Mg-Al oxides are modulated by changing the $\mathrm{Mg} / \mathrm{Al}$ ratios, calcination temperature and treatment with probe molecules. Detailed characterization, including X-ray diffraction, ${ }^{27} \mathrm{Al}$ magic angle spinning nuclear magnetic resonance spectroscopy, $\mathrm{N}_{2}$-adsorption, $\mathrm{NH}_{3}$-temperature-programmed desorption, $\mathrm{CO}_{2}$-temperature-programmed desorption and X-ray photoelectron spectroscopy are carried out to determine the physicochemical properties of these catalysts. The $\mathrm{Mg}-\mathrm{Al}$ oxides with $\mathrm{Mg} / \mathrm{Al}=3$ exhibit the highest activity in the reaction, which possess a large number of surface weak basic sites and a relatively small number of weak acidic sites. The role of the acidic and basic sites in the reaction process is systematically investigated, and are shown to serve as adsorption and activation sites for amines and alcohols, respectively. Under the synergistic effect of these acid-base centers, the oxidative coupling process successfully occurs on the surface of Mg-Al mixed oxides. Compared with the acidic sites, the weak basic sites play a more important role in the catalytic process. The acidic sites are the catalytic centers for the benzyl alcohol activation, which control the reaction rate of the oxidative coupling reaction.
\end{abstract}

(C) 2018, Dalian Institute of Chemical Physics, Chinese Academy of Sciences. Published by Elsevier B.V. All rights reserved.

\section{Introduction}

Owing to the presence of the reactive $\mathrm{C}=\mathrm{N}$ moiety, imines are an important nitrogen source in the fields of biology, medicine and agriculture [1-5]. A series of valuable nitrogen-containing derivatives can be synthesized through some simple chemical processes [6-8]. In industrial processes, most imine-containing compounds are obtained by condensing carbonyl compounds and primary amines under strongly acidic conditions [9-11]. Compared with this route, direct oxidative coupling of alcohols and amines to imines in the presence of air or oxygen is a more benign synthetic route, which is currently being intensively researched $[12,13]$.

Supported noble metal catalysts, such as Pd, Pt and Au, exhibit certain catalytic properties in the presence of alkali as additives or by using basic oxides as supports [14-20]. Considering the cost and environmental friendliness of catalysts, significant research has been devoted to developing transition metal oxide catalysts. Some reducible metal oxides, such as $\mathrm{MnO}_{2}, \mathrm{Fe}_{2} \mathrm{O}_{3}, \mathrm{~V}_{2} \mathrm{O}_{5}$ and $\mathrm{CeO}_{2}$, have been reported to catalyze this

\footnotetext{
* Corresponding author. Tel: +86-431-85155390; Fax: +86-431-88499140; E-mail: zhwenx@jlu.edu.cn

\# Corresponding author. Tel: +86-431-85155390; Fax: +86-431-88499140; E-mail: lgang@jlu.edu.cn

This work was supported by the National Natural Science Foundation of China $(21473073,21473074)$, the Development Project of Science and Technology of Jilin Province (20170101171JC), "13th Five-Year" science and technology research of the Education Department of Jilin Province (2016403) and the Open Project of State Key Laboratory of Inorganic Synthesis and Preparative Chemistry (201703).

DOI: 10.1016/S1872-2067(17)63006-7 | http://www.sciencedirect.com/science/journal/18722067 | Chin. J. Catal., Vol. 39 , No. 2, February 2018
} 
reaction [21-25]. Our recent work showed that the reducibility of the transition metal oxides, which could directly influence the activation of molecular oxygen, was an important factor affecting the activity of the catalyst [26,27]. The activity can be improved by optimizing the particle size or morphology of the metal oxides. However, the influence of other factors, such as the surface acidity and basicity of catalysts have been ignored in this reaction previously [28]. Some valuable solid acid-base catalysts composed of environmentally-friendly non-reducible metals have also been ignored in the previous work.

From the viewpoint of the reaction mechanism, a solid acid-base catalyst should also be suitable for this reaction. Generally, the title reaction undergoes two consecutive steps: (1) oxidative dehydrogenation of the alcohol to benzaldehyde and (2) condensation of benzaldehyde with aniline [23,29,30]. Current research based on transition metal oxides have shown that step (1) mainly occurs on the redox center, while step (2) mainly occurs on the acidic center [6,31]. It is known that a solid base can also be used as an effective dehydrogenation active center in many catalytic processes [32]. Therefore, it is possible to construct a solid acid-base catalyst suitable for the above reaction by regulating the surface acid-base center of the catalyst.

Based on this hypothesis, Mg-Al mixed oxides were introduced as catalysts in the oxidative coupling of alcohols and amines to imine. The surface acid-base properties of $\mathrm{Mg}-\mathrm{Al}$ oxides were modulated by changing the $\mathrm{Mg} / \mathrm{Al}$ ratios, calcination temperature and treatment with probe molecules. Under the optimized conditions, $\mathrm{Mg}-\mathrm{Al}$ mixed oxides with $\mathrm{Mg} / \mathrm{Al}=3$ exhibited a relatively high activity in this reaction, which was comparable with that of supported $\mathrm{FeO}_{x}$ catalysts reported previously [26]. Various characterizations, including X-ray diffraction (XRD), ${ }^{27} \mathrm{Al}$ magic angle spinning nuclear magnetic resonance spectroscopy (MAS NMR), $\mathrm{N}_{2}$-adsorption, $\mathrm{NH}_{3}$-temperature-programmed desorption (TPD), $\mathrm{CO}_{2}$-TPD and X-ray photoelectron spectroscopy (XPS) were performed to investigate the structure and surface properties of $\mathrm{Mg}-\mathrm{Al}$ oxides. A series of detailed treatment conditions and catalytic tests were also carried out to clarify the influence of the surface acid-base properties on the catalytic performance for the oxidative coupling of alcohols and amines.

\section{Experimental}

\subsection{Catalyst preparation}

An Mg-Al mixed oxides catalyst was prepared by a co-precipitation method. In a typical process, a certain amount of $\mathrm{Mg}\left(\mathrm{NO}_{3}\right)_{2} \cdot 6 \mathrm{H}_{2} \mathrm{O}$ and $\mathrm{Al}\left(\mathrm{NO}_{3}\right)_{3} \cdot 9 \mathrm{H}_{2} \mathrm{O}$ was dissolved in $200 \mathrm{~mL}$ deionized water. After $0.5 \mathrm{~h}$ stirring, $12.5 \% \mathrm{NH}_{3} \cdot \mathrm{H}_{2} \mathrm{O}$ added to the mixture to adjust the $\mathrm{pH}$ value to 9.0. After continuous stirring for $2 \mathrm{~h}$, the mixture was filtrated and washed with deionized water. The obtained solids were dried in an oven at $80{ }^{\circ} \mathrm{C}$ overnight, and then calcined at $500{ }^{\circ} \mathrm{C}$ for $4 \mathrm{~h}$ in a muffle furnace. $\mathrm{The} \mathrm{Mg} / \mathrm{Al}$ ratio of $\mathrm{Mg}$-Al mixed oxides was adjusted from 0.33 to 5.0 by changing the amount of $\mathrm{Mg}\left(\mathrm{NO}_{3}\right)_{2} \cdot 6 \mathrm{H}_{2} \mathrm{O}$ and $\mathrm{Al}\left(\mathrm{NO}_{3}\right)_{3} \cdot 9 \mathrm{H}_{2} \mathrm{O}$ in the initial process. For comparison, $\mathrm{MgO}$ and
$\mathrm{Al}_{2} \mathrm{O}_{3}$ were also prepared using the same method as the Mg-Al mixed oxides.

\subsection{Catalyst characterization}

The X-ray diffraction (XRD) patterns were recorded on a Rigaku X-ray diffractometer using $\mathrm{Cu} K_{\alpha}$ radiation $(\lambda=0.15418$ $\mathrm{nm})$ at $40 \mathrm{kV}$ and $40 \mathrm{~mA}$. $\mathrm{N}_{2}$ adsorption-desorption isotherms were measured at $-196{ }^{\circ} \mathrm{C}$, using a Micromeritics ASAP 2010N analyzer. Samples were degassed at $200{ }^{\circ} \mathrm{C}$ for $20 \mathrm{~h}$ before measurements. Specific surface areas were calculated using the Brunauer-Emmett-Teller (BET) model. Pore size distributions were evaluated from desorption branches of nitrogen isotherms using the Barret-Joyner-Halenda (BJH) model. Scanning electron microscopy (SEM) was performed using an HITACHI SU8020 instrument with $30 \mathrm{kV}$. XPS data were obtained on a Thermo ESCA LAB 250 system with a Mg $K_{\alpha}$ source (1254.6 eV). TPD was performed on a ChemBET Pulsar TPR/TPD instrument (Quantachrome Instruments). Before detection, the catalysts $\left(50 \mathrm{mg}\right.$ ) were first treated in a $\mathrm{N}_{2}(99.99 \%)$ flow at $500{ }^{\circ} \mathrm{C}$ for $0.5 \mathrm{~h}$. The ${ }^{27} \mathrm{Al}$ MAS spectra were recorded on a Bruker AVANCE III 400 WB spectrometer equipped with a 4 $\mathrm{mm}$ standard bore CP MAS probe-head whose X channel was tuned to $104.27 \mathrm{MHz}$ for ${ }^{27} \mathrm{Al}$, where pulse sequence was one pulse $(0.9 \mu \mathrm{s}, \pi / 12)$, using a magnetic field of $9.39 \mathrm{~T}$ at $24{ }^{\circ} \mathrm{C}$. The dried and finely powdered samples were packed in the $\mathrm{ZrO}_{2}$ rotor closed with a Kel-F cap and were spun at $12 \mathrm{kHz}$ rate. A total of 100 scans were recorded with a 2 s recycle delay for each sample. All ${ }^{27} \mathrm{Al} \mathrm{MAS}$ chemical shifts were referenced to the resonances of $\left[\mathrm{Al}\left(\mathrm{H}_{2} \mathrm{O}\right)_{6}\right]^{3+}$ with standard $(d=0.00)$.

\subsection{Catalyst screening}

Catalytic screening for the oxidative coupling of alcohols and amines was carried out as follows: a 50-mL two-neck flask was charged with toluene $(10 \mathrm{~mL})$, catalyst $(0.3 \mathrm{~g}), 1.0 \mathrm{mmol}$ benzyl alcohol and $2.0 \mathrm{mmol}$ aniline. The flask was placed in an $80{ }^{\circ} \mathrm{C}$ oil bath and connected with a balloon full of air. The products were extracted with a sampling pipe equipped with a filter, and the analyses were performed on a gas-chromatograph equipped with an HP-5 column and FID detector. The corresponding alcohols and amines and imines were used as standards.

The oxygen-free experiment was carried out in a Schlenk tube. First, the catalyst was put in the Schlenk tube and degassed for $1.5 \mathrm{~h}$ under vacuum. The tube was then charged with nitrogen (99.99\%). The above procedure was repeated three times. Then the degassed reagents were introduced into the Schlenk tube and the tube was placed in an $80{ }^{\circ} \mathrm{C}$ oil bath. For the recycling experiment, the solid catalyst was separated by filtration after reaction without any washing treatment. Before another reaction, the catalyst was calcined at $500{ }^{\circ} \mathrm{C}$ for $1 \mathrm{~h}$ to remove the adsorbed reactants.

To understand the role of the acid-base sites in the reaction, pyridine and pyrrole poisoning experiments were carried out over the $\mathrm{Mg}$-Al mixed oxide with $\mathrm{Mg} / \mathrm{Al}=3$. The detailed process was as following: the catalyst $(0.3 \mathrm{~g})$ was added to a mix- 
ture of toluene $(10 \mathrm{~mL})$ and pyridine/pyrrole $(100 \mu \mathrm{L})$. The mixture was stirred for $3 \mathrm{~h}$ at room temperature. The catalyst was then filtered out and washed with toluene several times.

\section{Results and discussion}

Fig. 1 shows the XRD patterns of pure $\mathrm{Al}_{2} \mathrm{O}_{3}, \mathrm{MgO}$ and $\mathrm{Mg}-\mathrm{Al}$ oxides with different $\mathrm{Mg} / \mathrm{Al}$ ratios. All these samples were prepared with the same precipitation method, and ammonia solution was used as the $\mathrm{pH}$ adjusting agent. The samples were all calcined at $500{ }^{\circ} \mathrm{C}$ for $4 \mathrm{~h}$ before use as catalysts and characterization. As for $\mathrm{Al}_{2} \mathrm{O}_{3}$, the weak diffraction peaks centered at $2 \theta$ $=37.5^{\circ}, 39.5^{\circ}, 45.9^{\circ}$ and $66.7^{\circ}$ could be assigned to the (311), (222), (400), (440) planes of the $\gamma$-phase $\mathrm{Al}_{2} \mathrm{O}_{3}$, which was consistent with the JCPDS Card 10-0425 [33]. As for MgO, three diffraction peaks centered at $2 \theta=37.0^{\circ}, 43.0^{\circ}$ and $62.5^{\circ}$ could be observed, which were assigned to the (111), (200) and (220) planes of MgO (JCPDS Card 77-2364) [34]. As for Mg-Al oxides with different $\mathrm{Mg} / \mathrm{Al}$ ratios, a mixed phase existed in all the samples. According to the JCPDS Card 33-0853, the main diffraction peaks of $\mathrm{MgAl}_{2} \mathrm{O}_{4}$ are located at $2 \theta=36.8^{\circ}, 44.8^{\circ}$ and $65.6^{\circ}$, which are associated with the (311), (400) and (440) crystal planes of $\mathrm{MgAl}_{2} \mathrm{O}_{4}$. When $\mathrm{Mg} / \mathrm{Al} \leq 1$, both $\gamma-\mathrm{Al}_{2} \mathrm{O}_{3}$ and $\mathrm{MgAl}_{2} \mathrm{O}_{4}$ phases existed in the sample. The low intensity and broad peaks showed that the crystallinity of both $\gamma-\mathrm{Al}_{2} \mathrm{O}_{3}$ and $\mathrm{MgAl}_{2} \mathrm{O}_{4}$ phases was very low. When $2 \leq \mathrm{Mg} / \mathrm{Al} \leq 4$, the diffraction peak at approximately $2 \theta=36.8^{\circ}$ and $44.8^{\circ}$ broadened, and no obvious diffraction peaks assigned to the $\mathrm{MgO}$ phase could be observed. This result indicated that the $\mathrm{Al}^{3+}$ cations remained closely associated with the Mg-O and the local structure was amorphous. As for the sample with $\mathrm{Mg} / \mathrm{Al}=5$, additional peaks assigned to the MgO crystal phase could be observed.

NMR is a powerful local-probe measurement that can detect all the structures regardless of crystalline or amorphous phase [35]. It can effectively complement Powder XRD by probing amorphous phases where direct information could only be obtained from samples with crystalline structure. Fig. 2 shows the ${ }^{27} \mathrm{Al}$ MAS NMR spectra of Mg-Al oxides with four typical $\mathrm{Mg} / \mathrm{Al}$ ratios. There were two resonance peak in the areas around 8-10 ppm and 67-81 ppm, which could be assigned to $\mathrm{Al}^{3+}$ cations octahedrally $\left(\mathrm{Al}_{\mathrm{o}}\right)$ and tetrahedrally ( $\mathrm{Al}_{\mathrm{t}}$ ) coordi-

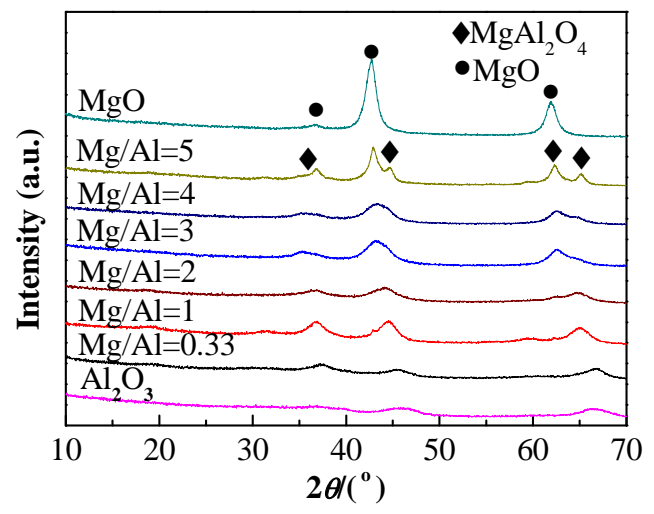

Fig. 1. XRD patterns of $\mathrm{Mg}-\mathrm{Al}$ mixed oxides with different $\mathrm{Mg} / \mathrm{Al}$ ratios.

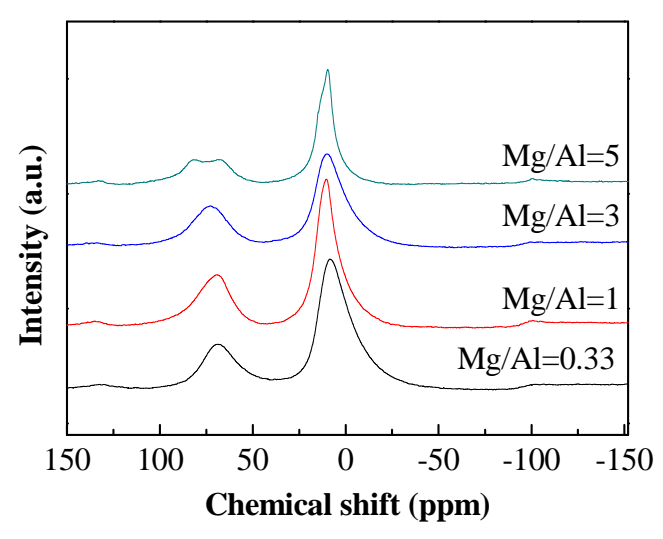

Fig. 2. ${ }^{27} \mathrm{Al}$ MAS NMR spectra of Mg-Al mixed oxides with different $\mathrm{Mg} / \mathrm{Al}$ ratios.

nated to oxygen, respectively [36-38]. With the increase of the $\mathrm{Mg} / \mathrm{Al}$ ratio, the peaks of $\mathrm{Al}_{\mathrm{o}}$ and $\mathrm{Al}_{\mathrm{t}}$ were slightly shifted downfield. This result suggested that electronegative $\mathrm{Al}^{3+}$ was being replaced by more electropositive $\mathrm{Mg}^{2+}$ as the nearest neighbor cation bonded to the Al-0 polyhedral [39]. Different results were obtained for the $\mathrm{Mg} / \mathrm{Al}=5$ sample, in which the peak assigned to $\mathrm{Al}_{\mathrm{t}}$ split into two peaks and the peak assigned to $\mathrm{Al}_{\mathrm{o}}$ moved to a lower chemical shift. This result mainly arose from the formation of the $\mathrm{MgO}$ and $\mathrm{MgAl}_{2} \mathrm{O}_{4}$ crystal phases at this $\mathrm{Mg} / \mathrm{Al}$ ratio [40].

Combined with the results of XRD and ${ }^{27} \mathrm{Al}$ MAS NMR, it was shown that as the Mg content increased, more and more $\mathrm{Mg}^{2+}$ cations bonded to the Al-O polyhedral forming Mg-O-Al. When $\mathrm{Mg} / \mathrm{Al} \leq 4$, although some $\mathrm{MgO}$ and $\mathrm{MgAl}_{2} \mathrm{O}_{4}$ units were present in the sample, the samples still generally possessed the property of the amorphous state. The relatively wide XRD diffraction peaks supported this deduction. When $\mathrm{Mg} / \mathrm{Al}$ was increased to 5, the formed $\mathrm{MgO}$ crystal phase broke the original bonding balance. Both $\mathrm{MgO}$ and $\mathrm{MgAl}_{2} \mathrm{O}_{4}$ crystalline phases could be clearly observed in the XRD patterns. Furthermore, the ${ }^{27} \mathrm{Al}$ MAS NMR spectra also showed that $\mathrm{Al}^{3+}$ cations in all the sample preferentially located in the octahedral positions. Comparing these samples, the $\mathrm{Al}_{\mathrm{o}} / \mathrm{Al}_{\mathrm{t}}$ values decreased from 2.89 for $\mathrm{Mg} / \mathrm{Al}=0.33$ to 2.04 for $\mathrm{Mg} / \mathrm{Al}=1.0$, and then remained approximately constant when the $\mathrm{Mg} / \mathrm{Al}$ ratio was increased further.

Fig. 3(a) shows the $\mathrm{N}_{2}$ adsorption-desorption isotherms of pure $\mathrm{Al}_{2} \mathrm{O}_{3}, \mathrm{MgO}$ and $\mathrm{Mg}-\mathrm{Al}$ oxides with different $\mathrm{Mg} / \mathrm{Al}$ ratios. All these samples exhibited a type IV isotherm, which indicated a mesoporous character [41,42]. Most of the hysteresis loops located at a relatively high pressure $\left(p / p_{0}\right)$ zone, which indicated the presence of a relatively large pore size. Pore size distribution plots showed that the most integrable pore size of $\mathrm{Mg}$ - $\mathrm{Al}$ oxides with different $\mathrm{Mg} / \mathrm{Al}$ ratios was centered at around 10-15 nm (Fig. 3(b)). The specific surface area showed a decreasing trend with the increase of the $\mathrm{Mg} / \mathrm{Al}$ ratio (see Table 1). As for pure $\mathrm{Al}_{2} \mathrm{O}_{3}$, a relatively small pore size (around $5 \mathrm{~nm}$ ) could be observed. As for pure $\mathrm{MgO}$, the wide pore size distribution meant that the pores in the sample were mostly derived from the accumulated pores between particles. SEM 

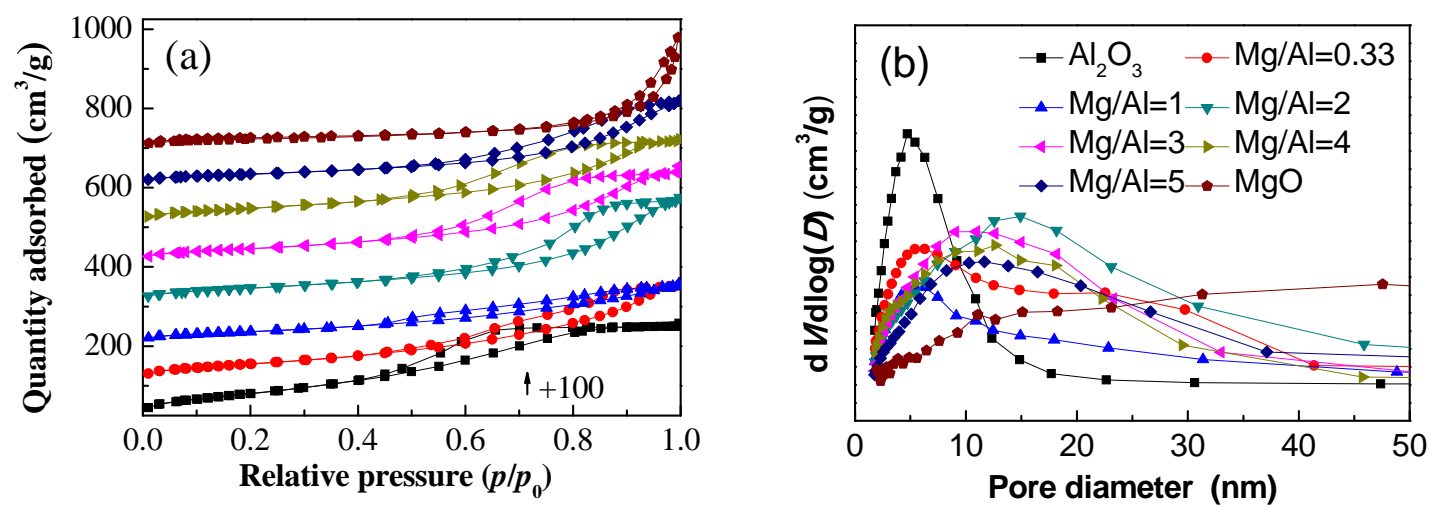

Fig. 3. $\mathrm{N}_{2}$ adsorption-desorption isotherms (a) and pore size distribution plots (b) of Mg-Al mixed oxides with different $\mathrm{Mg} / \mathrm{Al}$ ratios.

images further confirmed the results from $\mathrm{N}_{2}$-adsorption that a large amount of mesopores arose from the packing holes between the particles (Fig. 4). When the $\mathrm{Mg} / \mathrm{Al}$ ratio was increased to 5 , relatively large particles and pores could be clearly observed. This mainly arose from the remarkable crystallization occurring at such a high $\mathrm{Mg} / \mathrm{Al}$ ratio.

The surface acidic and basic properties of the samples were investigated by TPD measurements using $\mathrm{NH}_{3}$ and $\mathrm{CO}_{2}$ as probe molecules, respectively. Fig. 5(a) shows the $\mathrm{NH}_{3}$ - TPD profiles of pure $\mathrm{Al}_{2} \mathrm{O}_{3}, \mathrm{MgO}$ and $\mathrm{Mg}$-Al oxides with different $\mathrm{Mg} / \mathrm{Al}$ ratios. All these samples exhibited a broad desorption peak in the detection region, which indicated the relatively complex surface acidic nature of these samples. The TPD profiles were deconvoluted into four desorption peaks (Fig. 5(a) and Table 2). According to the literature, the low-temperature peak could be assigned to a reversible $\mathrm{H}$-bonded adsorption on Brönsted sites, and the high-temperature peak could be attributed to the irreversible coordinated adsorption on the Lewis sites $[43,44]$. These Lewis sites included $\mathrm{Al}^{3+}$ cations in $\mathrm{Al}^{3+-} \mathrm{O}^{2--} \mathrm{Mg}^{2+}$ and $\mathrm{Al}^{3+-} \mathrm{O}^{2-}$ species, and $\mathrm{Mg}^{2+}$ cations in $\mathrm{Mg}^{2+-} \mathrm{O}^{2-}$ species [45-48]. From the perspective of total acidity, the largest surface acidity appeared in the $\mathrm{Mg} / \mathrm{Al}=0.33$ samples. With the increase of the $\mathrm{Mg} / \mathrm{Al}$ ratio, the total surface acidity decreased first and then increased. The sample of MgO exhibited the lowest surface acidity.

The $\mathrm{CO}_{2}$-TPD profiles (Fig. 5(b)) showed that the surface basic properties of these samples were also complex. A series

Table 1

Texture properties of Mg-Al mixed oxides with different Mg/Al ratios.

\begin{tabular}{lcccc}
\hline Sample & $\begin{array}{c}S_{\text {BET }} \\
\left(\mathrm{m}^{2} \cdot \mathrm{g}^{-1}\right)\end{array}$ & $\begin{array}{c}\text { Pore volume } \\
\left(\mathrm{cm}^{3} \cdot \mathrm{g}^{-1}\right)\end{array}$ & $\begin{array}{c}\text { Pore size } \\
(\mathrm{nm})\end{array}$ & $\begin{array}{c}\text { Surface } \mathrm{Mg} / \mathrm{Al} \\
\text { ratios }\end{array}$ \\
\hline $\mathrm{Al}_{2} \mathrm{O}_{3}$ & 296 & 0.39 & 5.2 & - \\
$\mathrm{Mg} / \mathrm{Al}=0.33$ & 203 & 0.39 & 7.6 & 0.06 \\
$\mathrm{Mg} / \mathrm{Al}=1$ & 165 & 0.26 & 6.8 & 1.03 \\
$\mathrm{Mg} / \mathrm{Al}=2$ & 171 & 0.40 & 9.4 & - \\
$\mathrm{Mg} / \mathrm{Al}=3$ & 168 & 0.36 & 8.6 & 1.38 \\
$\mathrm{Mg} / \mathrm{Al}=4$ & 176 & 0.33 & 7.6 & - \\
$\mathrm{Mg} / \mathrm{Al}=5$ & 125 & 0.32 & 10.3 & 2.32 \\
$\mathrm{MgO}$ & 92 & 0.27 & 11.6 & - \\
\hline
\end{tabular}

a Calculated from adsorption branches using BJH model. ${ }^{\mathrm{b}}$ Detected by XPS.

of basic centers with different strengths were present on the surface of all these samples. They separately came from $\mathrm{OH}^{-}$ groups, $\mathrm{Mg}-\mathrm{O}$ pairs, $\mathrm{Al}-\mathrm{O}$ pairs and $\mathrm{O}^{2-}$ anions [43-45]. As for the $\mathrm{Mg}$-Al oxides, with an increase of the $\mathrm{Mg}$ content, the total number of surface basic sites increased at first then decreased. The largest number of surface basic sites was present in the $\mathrm{Mg} / \mathrm{Al}=3$ samples $\left(89.8 \mu \mathrm{mol} \cdot \mathrm{g}^{-1}\right)$. A large number of weak basic centers existed on the surface of the sample $(25.9$ $\mu \mathrm{mol} \cdot \mathrm{g}^{-1}$ ), which accounted for $28.8 \%$ of the surface basic centers (Table 2).

The above results showed that the change of surface acidity and basicity was closely related to the $\mathrm{Mg} / \mathrm{Al}$ ratio of the samples. However, it should be noted that the composition of surface $\mathrm{Mg} / \mathrm{Al}$ was not consistent with that of the body. Table 1 shows that the surface $\mathrm{Mg} / \mathrm{Al}$ was much lower than that of the stoichiometric ratio, which indicated that more $\mathrm{Mg}$ atoms entered into the bulk of the samples. This part of the Mg atoms indirectly affected the acid-base properties of the catalyst sur-
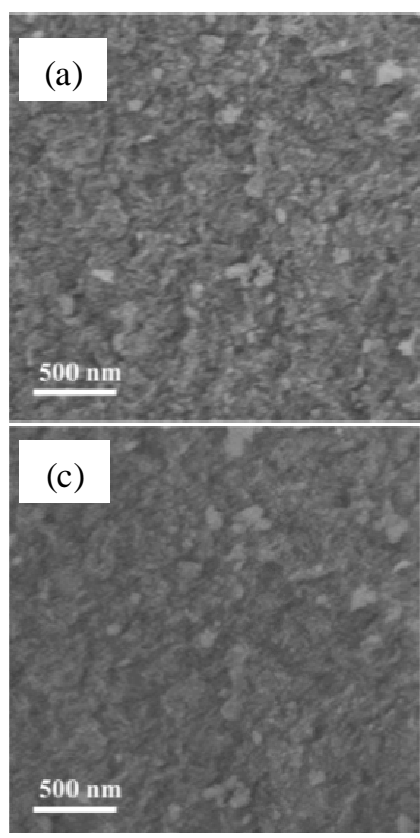

Fig. 4. SEM images of $\mathrm{Mg}-\mathrm{Al}$ mixed oxides with different $\mathrm{Mg} / \mathrm{Al}$ ratios: (a) $\mathrm{Mg} / \mathrm{Al}=0.33$, (b) $\mathrm{Mg} / \mathrm{Al}=1$, (c) $\mathrm{Mg} / \mathrm{Al}=3$, and (d) $\mathrm{Mg} / \mathrm{Al}=5$.
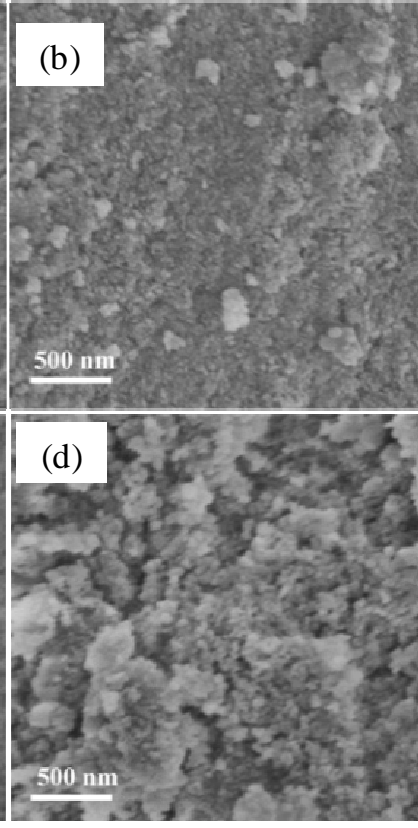

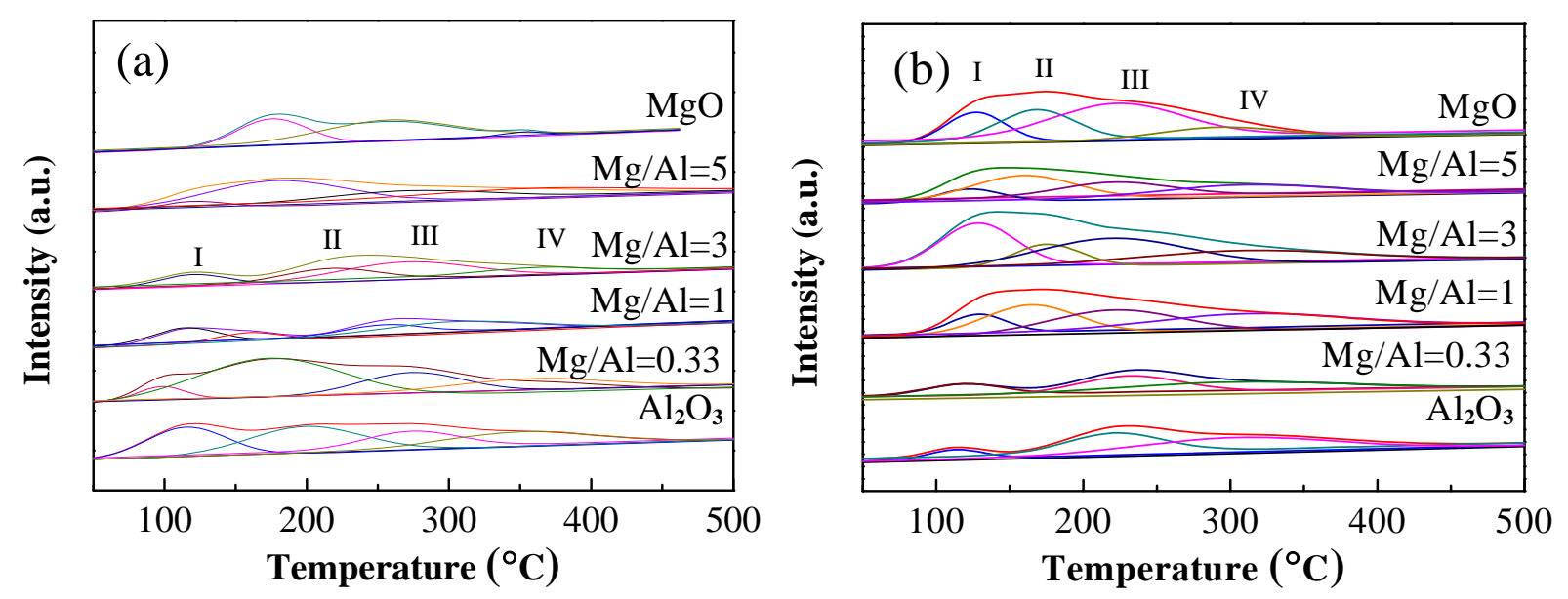

Fig. 5. $\mathrm{NH}_{3}-\mathrm{TPD}(\mathrm{a})$ and $\mathrm{CO}_{2}$-TPD (b) profiles of $\mathrm{Mg}$-Al mixed oxides with different $\mathrm{Mg} / \mathrm{Al}$ ratios.

Table 2

Characterization of the acid-base properties of $\mathrm{Al}_{2} \mathrm{O}_{3}, \mathrm{MgO}$ and $\mathrm{Mg}$ - $\mathrm{Al}$ mixed oxides with different $\mathrm{Mg} / \mathrm{Al}$ ratios.

\begin{tabular}{|c|c|c|c|c|c|c|c|c|c|c|}
\hline \multirow{2}{*}{ Sample } & \multicolumn{4}{|c|}{$\mathrm{NH}_{3}-\mathrm{TPD}\left(\mu \mathrm{mol} \cdot \mathrm{g}^{-1}\right)$} & \multirow{2}{*}{$\begin{array}{l}\text { Total acid amount } \\
\quad\left(\mu \mathrm{mol} \cdot \mathrm{g}^{-1}\right)\end{array}$} & \multicolumn{4}{|c|}{$\mathrm{CO}_{2}-\mathrm{TPD}\left(\mu \mathrm{mol} \cdot \mathrm{g}^{-1}\right)$} & \multirow{2}{*}{$\begin{array}{c}\text { Total base amount } \\
\left(\mu \mathrm{mol} \cdot \mathrm{g}^{-1}\right)\end{array}$} \\
\hline & Peak I & Peak II & Peak III & Peak IV & & Peak I & Peak II & Peak III & Peak IV & \\
\hline $\mathrm{Al}_{2} \mathrm{O}_{3}$ & 17.4 & 21.6 & 11.6 & 15.8 & 66.4 & 4.0 & - & 15.0 & 23.1 & 42.0 \\
\hline $\mathrm{Mg} / \mathrm{Al}=0.33$ & 4.4 & 43.4 & 15.6 & 11.9 & 75.4 & 6.6 & - & 13.7 & 15.9 & 36.2 \\
\hline $\mathrm{Mg} / \mathrm{Al}=1$ & 6.8 & 4.1 & 5.3 & 12.8 & 29.1 & 8.2 & 21.3 & 24.1 & 22.3 & 72.0 \\
\hline $\mathrm{Mg} / \mathrm{Al}=3$ & 5.9 & 8.5 & 16.3 & 4.1 & 34.8 & 25.9 & 12.2 & 32.9 & 18.8 & 89.8 \\
\hline $\mathrm{Mg} / \mathrm{Al}=5$ & 4.0 & 24.2 & 9.2 & 11.1 & 49.2 & 9.7 & 30.9 & 10.8 & 22.9 & 74.4 \\
\hline $\mathrm{MgO}$ & - & 8.7 & 17.6 & 1.2 & 27.5 & 14.1 & 18.5 & 34.3 & 11.8 & 78.7 \\
\hline
\end{tabular}

face through bonding with Al species (detected from NMR). With the increase of the Mg content, the $01 s$ XPS spectra (Fig. 6) shifted slightly toward a lower binding energy, which was consistent with the change of the surface basic properties. It should be noted that the total base amount of the Mg-Al oxides in our case was lower than that in some reports [41-43,49,50]. This was closely related to the distribution of surface $\mathrm{Mg} / \mathrm{Al}$ elements. XPS results clearly showed that the sample prepared under our conditions possessed relatively low surface $\mathrm{Mg} / \mathrm{Al}$ ratios compared with the samples reported previously.

Fig. 7(a) shows the catalytic activity of the above samples in the oxidative coupling of benzyl alcohol and aniline to an imine at $80{ }^{\circ} \mathrm{C}$. The mole ratio of benzyl alcohol to aniline in the reagent was 1:2. The yield of imine was calculated using benzyl alcohol as the standard. The selectivity calculated based on benzyl alcohol was larger than 99\%. Therefore, the conversion of benzyl alcohol was almost the same as the yield (not shown here). Fig. 7(a) shows that both $\mathrm{MgO}$ and $\mathrm{Al}_{2} \mathrm{O}_{3}$ exhibited a low activity in this reaction. Only a $19.2 \%$ and $22.7 \%$ yield of imine could be observed over $\mathrm{MgO}$ and $\mathrm{Al}_{2} \mathrm{O}_{3}$ after reaction for $8 \mathrm{~h}$. As for the Mg-Al oxides, the introduction of a small amount of $\mathrm{Mg}$ significantly improved the activity of the sample. When $\mathrm{Mg} / \mathrm{Al}=$ 3 , the yield of imine could reach to $93.5 \%$ (with benzyl alcohol and aniline as substrates) after reaction for $8 \mathrm{~h}$. The activity could be further improved when the reaction temperature was increased from $80^{\circ} \mathrm{C}$ to $100{ }^{\circ} \mathrm{C}$. This result was comparable with that of the supported $\mathrm{FeO}_{x}$ catalysts reported previously [26]. When $\mathrm{Mg} / \mathrm{Al}$ was further increased, the activity of the samples decreased compared with that of the sample with
$\mathrm{Mg} / \mathrm{Al}=3$, but it was still higher than that of the $\mathrm{MgO}$ and $\mathrm{Al}_{2} \mathrm{O}_{3}$ samples. It should be pointed out that a trace amount of by-product, azoxybenzene, could be detected by GC. It was identified with Gas chromatography-mass spectrometry and a standard reagent. This by-product arose from the condensation of a small amount of aniline.

As for the sample with $\mathrm{Mg} / \mathrm{Al}=3$, a hot filtration test was carried out to confirm the heterogeneous nature of the sample. The results showed that $\mathrm{Mg}-\mathrm{Al}$ oxides behaved as an operationally heterogeneous catalyst, since the imine concentration in the filtrate did not increase (Fig. 7(b)). Almost no $\mathrm{Mg}$ and $\mathrm{Al}$

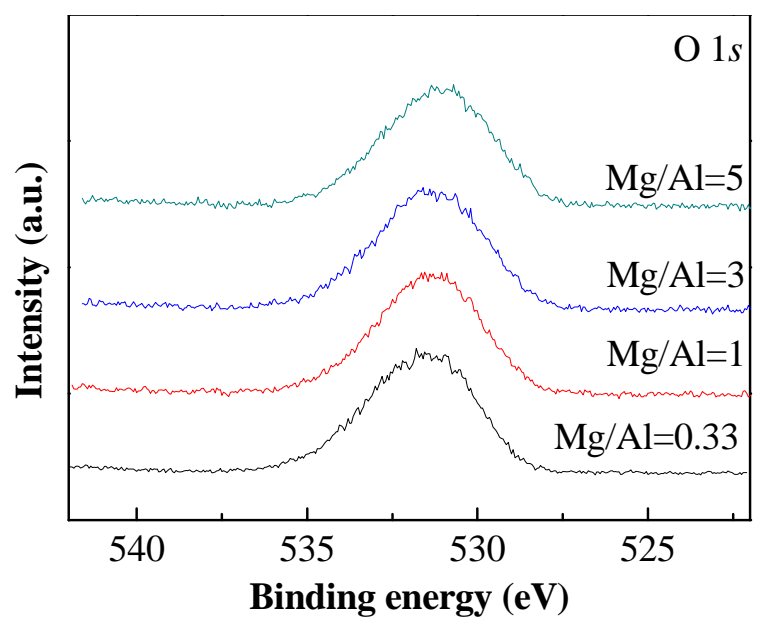

Fig. 6. $01 s$ XPS spectra of Mg-Al mixed oxides with different $\mathrm{Mg} / \mathrm{Al}$ ratios. 

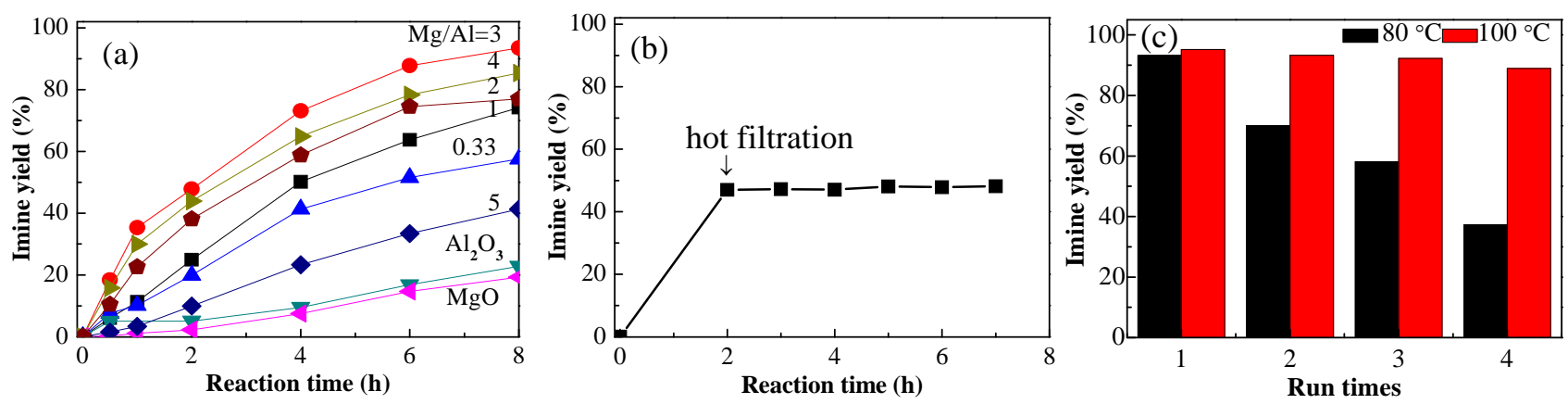

Fig. 7. (a) Catalytic performances of Mg-Al mixed oxides with different $\mathrm{Mg} / \mathrm{Al}$ ratios at $80{ }^{\circ} \mathrm{C}$. Reaction conditions: benzyl alcohol $(1 \mathrm{mmol})$, aniline $(2$ mmol), catalyst $(0.3 \mathrm{~g})$, toluene $(10 \mathrm{~mL})$, air $(0.1 \mathrm{MPa})$. (b) Leaching experiment of $\mathrm{Mg}$-Al mixed oxides $(\mathrm{Mg} / \mathrm{Al}=3)$ by continuing the reaction after filtration of the catalyst. The $2-7 \mathrm{~h}$ reaction result shows the imine yield after removing the catalysts. (c) Reusability of $\mathrm{Mg}-\mathrm{Al}$ mixed oxides (Mg/Al=3) for the reaction at $80^{\circ} \mathrm{C}$ and $100^{\circ} \mathrm{C}$. Reaction conditions: benzyl alcohol ( $\left.1 \mathrm{mmol}\right)$, aniline (2 mmol), catalyst ( $\left.0.3 \mathrm{~g}\right)$, toluene (10 mL), air ( $\left.0.1 \mathrm{Mpa}\right)$.

species in the filtration could be detected by ICP measurement. Furthermore, multiple reaction cycles were performed to investigate the recoverability of this sample. Two separate reactions were carried out at 80 and $100{ }^{\circ} \mathrm{C}$, respectively (Fig. 7(c)). After four cycles, the catalyst in the reaction at $100{ }^{\circ} \mathrm{C}$ still retained a high activity, whereas the activity of the catalyst in the reaction at $80{ }^{\circ} \mathrm{C}$ decreased significantly. It could be concluded that the adsorption and desorption of reactants and products on the catalyst surface have an important effect on the cyclic use of the catalyst. The adsorbed species could destroy the structure of Mg-Al oxides during the following thermal treatment. The surface area detected by $\mathrm{N}_{2}$-adsorption decreased from $168 \mathrm{~m}^{2} \cdot \mathrm{g}^{-1}$ to $39 \mathrm{~m}^{2} \cdot \mathrm{g}^{-1}$. A relatively high reaction temperature was favorable for the desorption of products, which is beneficial for the recycling of catalysts.

It is known that $\mathrm{Mg}$-Al oxides, as well as $\mathrm{MgO}$ and $\mathrm{Al}_{2} \mathrm{O}_{3}$, are all irreducible metal oxides. The catalytic process should be quite different from the reducible metal oxide catalysts reported previously [21-26]. Combined with the above characterization results, it could be proposed that the surface acid-base sites of Mg-Al oxides catalyst should be the main active sites for the oxidative coupling of benzyl alcohol and aniline. The influence of $\mathrm{Mg} / \mathrm{Al}$ ratio on the catalytic performance was also mainly manifested by the change of the surface acidity and basicity of the catalyst. To understand the role of the acid-base properties of the catalyst in the title reaction, we attempted to use pyridine (basic molecule) and pyrrole (weak acidic molecule) to poison part of the surface acidic and basic active sites of the Mg-Al oxide catalyst $(\mathrm{Mg} / \mathrm{Al}=3)$. The detailed pre-treatment process has been described in the Experimental section. Fig. 8 shows the catalytic performance of the poisoned catalysts. Compared with the untreated sample, the catalytic activity of both poisoned samples decreased. The sample treated with pyrrole exhibited a much lower activity than that treated with pyridine. This result indicated that the surface basic sites should play a more important role in the reaction. $\mathrm{NH}_{3}$-TPD and $\mathrm{CO}_{2}$-TPD results showed that the sample with $\mathrm{Mg} / \mathrm{Al}=3$ possessed a small number of surface acidic sites (34.8 $\mu \mathrm{mol} \cdot \mathrm{g}^{-1}$, Table 2) and a large number of surface basic sites $\left(89.8 \mu \mathrm{mol} \cdot \mathrm{g}^{-1}\right.$, Table 2$)$. Combined with the catalytic result, we could further confirm the important role of the surface basic sites in the oxidative coupling of benzyl alcohol and aniline.

To further understand the role of the surface acid-base properties in the catalytic process, we attempted to tune the surface properties of the sample $(\mathrm{Mg} / \mathrm{Al}=3)$ by changing the calcination temperature and then investigating their catalytic performance. XRD patterns (Fig. 9(a)) showed that the sample calcined at $400{ }^{\circ} \mathrm{C}$ (denoted as MgAl-400) exhibited a similar crystal structure to that calcined at $500{ }^{\circ} \mathrm{C}$ (the catalyst studied above, denoted as MgAl-500). The sample calcined at $800{ }^{\circ} \mathrm{C}$ (denoted as $\mathrm{MgAl}-800$ ) contained more $\mathrm{MgAl}_{2} \mathrm{O}_{4}$ crystalline phases compared with the other two samples. $\mathrm{N}_{2}$-adsorption results showed that MgAl-400 exhibited a similar specific surface area to $\mathrm{MgAl}-800$, which was 97.1 and $102.1 \mathrm{~m}^{2} \cdot \mathrm{g}^{-1}$, respectively. These were a little lower than that of MgAl-500 (167.9 $\mathrm{m}^{2} \cdot \mathrm{g}^{-1}$, Table 3). The catalytic result showed that MgAl-500 exhibited a higher activity than MgAl-800. Whereas the MgAl-400 sample showed a very low activity under the same reaction conditions (Fig. 9 (b)). $\mathrm{NH}_{3}$-TPD results (Fig. 10(a)) showed that all these samples possessed a certain number of acidic sites on the catalyst surface. Among them,

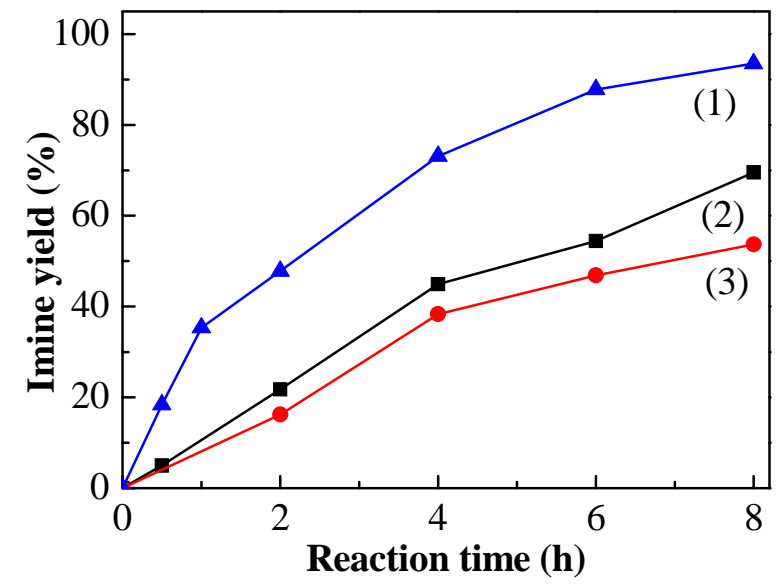

Fig. 8. Catalytic performance of $\mathrm{Mg}-\mathrm{Al}$ mixed oxides $(\mathrm{Mg} / \mathrm{Al}=3)$ treated under different conditions: (1) fresh sample, (2) pre-treated with pyridine, (3) pre-treated with pyrrole. Reaction conditions: benzyl alcohol (1 mmol), aniline (2 mmol), catalyst $(0.3 \mathrm{~g})$, toluene $(10 \mathrm{~mL})$, air $(0.1$ Мpa). 

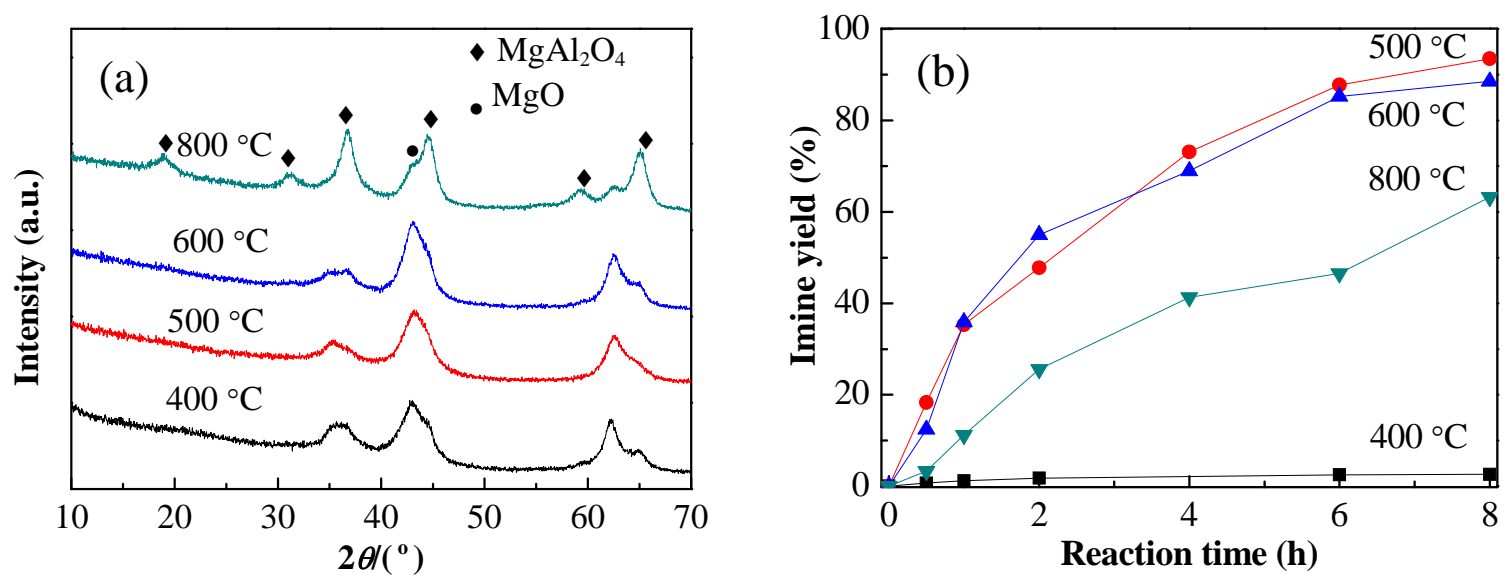

Fig. 9. (a) XRD patterns and (b) catalytic performances of Mg-Al mixed oxides with $\mathrm{Mg} / \mathrm{Al}=3$ calcined at different temperatures. Reaction conditions: benzyl alcohol $(1 \mathrm{mmol})$, aniline $(2 \mathrm{mmol})$, catalyst $(0.3 \mathrm{~g})$, toluene $(10 \mathrm{~mL}), 80^{\circ} \mathrm{C}$, air $(0.1 \mathrm{MPa})$.

Table 3

Texture properties of $\mathrm{Mg}$ - $\mathrm{Al}$ mixed oxides with $\mathrm{Mg} / \mathrm{Al}=3$ calcined at different temperatures.

\begin{tabular}{lccc}
\hline Sample & $S_{\text {BET }}\left(\mathrm{m}^{2} \cdot \mathrm{g}^{-1}\right)$ & Pore volume $\left(\mathrm{cm}^{3} \cdot \mathrm{g}^{-1}\right)$ & Pore size a $(\mathrm{nm})$ \\
\hline MgAl-400 & 97.1 & 0.23 & 9.4 \\
MgAl-500 & 167.9 & 0.36 & 8.6 \\
MgAl-600 & 128.3 & 0.28 & 8.8 \\
MgAl-800 & 102.1 & 0.36 & 14.1 \\
\hline
\end{tabular}

${ }^{a}$ Calculated from adsorption branches using BJH model.

MgAl-400 possessed the largest amount of weak acidic sites. The $\mathrm{CO}_{2}$-TPD (Fig. 10(b)) results showed that MgAl-400 was almost absent of weak basic sites, which was quite different to that for MgAl-500, MgAl-800 and the other samples studied above. The low activity of $\mathrm{MgAl}-400$ in the title reaction should mainly arise from the absence of weak basic sites on the catalyst surface. Combined with above results, it can be concluded that weak basic sites play a very important role in the oxidative coupling of benzyl alcohol and aniline. These weak basic sites should mainly provide adsorption sites for benzyl alcohol, which is a weak acidic reagent. Aniline ( $\mathrm{p} K a=4.63)$ was mainly adsorbed on the surface acidic sites of catalyst.

Our previous work has shown that oxidative dehydrogenation of benzyl alcohol is the rate-determining step in the reaction [26]. Over reducible oxide catalysts, the reaction proceeds in two consecutive steps, including oxidative dehydrogenation of alcohol to benzaldehyde and imine formation by reaction of benzaldehyde with aniline [23]. In this case, the step of oxidative dehydrogenation of alcohol to benzaldehyde hardly occurs on the irreducible Mg-Al oxides in the absence of aniline (Fig. 11(a)). This means that oxidative coupling of benzyl alcohol and aniline over $\mathrm{Mg}$-Al oxides should experience a different reaction path. Molecular $\mathrm{O}_{2}$ was demonstrated to be involved in this reaction since little imine can be observed in the absence of molecular $\mathrm{O}_{2}$ (Fig. 11(b)). However, the activation of molecular oxygen and benzyl alcohol is a relatively complex process, which needs participation by aniline. This point is quite different from that over the reducible oxides catalysts, such as supported $\mathrm{FeO}_{x}$ and $\mathrm{CeO}_{2}$, reported previously $[23,26]$. The cou-
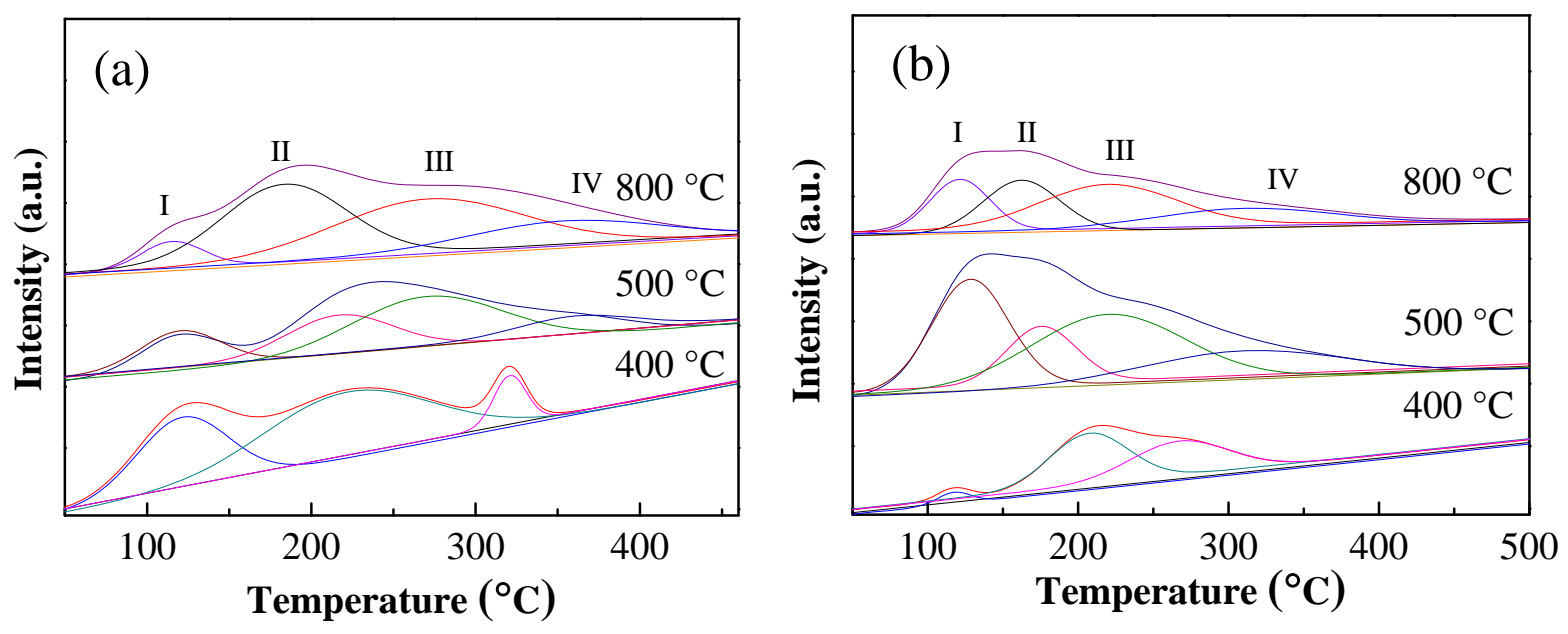

Fig. 10. (a) $\mathrm{NH}_{3}-\mathrm{TPD}$ and (b) $\mathrm{CO}_{2}$-TPD profiles of $\mathrm{Mg}-\mathrm{Al}$ mixed oxides with $\mathrm{Mg} / \mathrm{Al}=3$ calcined at different temperatures. 
Table 4

Characterization of acid-base properties of $\mathrm{Mg}$ - $\mathrm{Al}$ mixed oxides with $\mathrm{Mg} / \mathrm{Al}=3$ calcined at different temperatures.

\begin{tabular}{|c|c|c|c|c|c|c|c|c|c|c|}
\hline \multirow{2}{*}{ Sample } & \multicolumn{4}{|c|}{$\mathrm{NH}_{3}-\mathrm{TPD}\left(\mu \mathrm{mol} \cdot \mathrm{g}^{-1}\right)$} & \multirow{2}{*}{$\begin{array}{l}\text { Total acid amount } \\
\qquad\left(\mu \mathrm{mol} \cdot \mathrm{g}^{-1}\right)\end{array}$} & \multicolumn{4}{|c|}{$\mathrm{CO}_{2}-\mathrm{TPD}\left(\mu \mathrm{mol} \cdot \mathrm{g}^{-1}\right)$} & \multirow{2}{*}{$\begin{array}{c}\text { Total base amount } \\
\left(\mu \mathrm{mol} \cdot \mathrm{g}^{-1}\right)\end{array}$} \\
\hline & Peak I & Peak II & Peak III & Peak IV & & Peak I & Peak II & Peak III & Peak IV & \\
\hline MgAl-400 & 13.5 & 22.9 & 3.3 & - & 39.6 & 1.0 & 12.4 & 10.5 & - & 23.9 \\
\hline MgAl-500 & 5.9 & 8.5 & 16.3 & 4.1 & 34.8 & 25.9 & 12.2 & 32.9 & 18.8 & 89.8 \\
\hline MgAl-800 & 3.5 & 19.4 & 21.0 & 9.7 & 53.5 & 9.6 & 12.2 & 17.9 & 10.0 & 49.7 \\
\hline
\end{tabular}
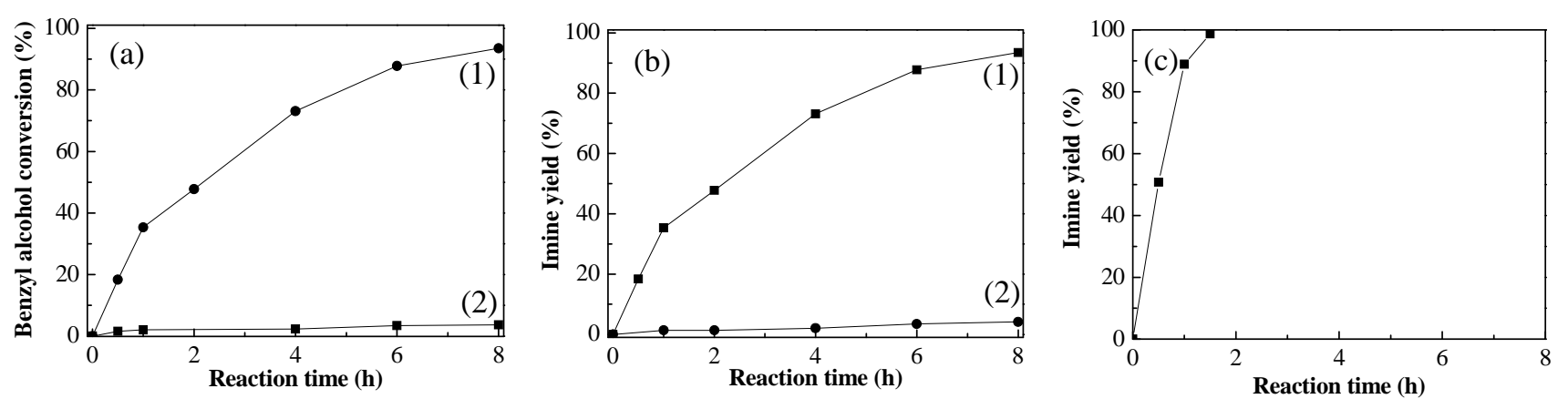

Fig. 11. (a) Benzyl alcohol oxidation (1) in the presence of aniline and (2) without aniline. (b) The coupling reaction of benzyl alcohol and aniline under (1) air (molecular oxygen) and (2) $\mathrm{N}_{2}$ (inert) conditions. (c) The coupling reaction of benzaldehyde and aniline in air.

pling of benzaldehyde and aniline is a fast step over Mg-Al oxide catalysts (Fig. 11(c)). Therefore, the activation of benzyl alcohol is still the rate-determining step for this oxidative coupling reaction although this process is not directly achieved by forming benzaldehyde. Further work is still needed to clarify the details of this process.

Furthermore, the general applicability of the Mg-Al oxides catalyst was also investigated. At least six kinds of imines could be obtained by oxidative coupling of amine with different alcohols. Table 5 shows that the Mg-Al mixed oxide catalyst was active in the reactions using benzyl alcohol derivatives with either electron-rich- or electron-poor-substituent groups, especially for 4-methoxy benzyl alcohol, 4-nitro benzyl alcohol and $p$-methyl benzyl alcohol (the yield of imine was $92.2 \%$,
$85.6 \%$ and $80.1 \%$ after $12 \mathrm{~h}$ reaction, respectively).

\section{Conclusions}

Mg-Al mixed oxides with various $\mathrm{Mg} / \mathrm{Al}$ ratios have been prepared by a co-precipitation method. They can effectively catalyze the oxidative coupling of alcohols and amines to imine. The sample with $\mathrm{Mg} / \mathrm{Al}=3$, which possesses a large amount of weak basic sites and a relatively small amount of weak acidic sites, exhibits the highest activity in the reaction. These acidic and basic sites serve as adsorption and activation sites for amines and alcohols, respectively. Among them, the weak basic sites play a more important role than the acidic sites in the catalytic process. They are the reactive centers for benzyl alco-

Table 5

Aerobic oxidative coupling of various alcohols and aniline over $\mathrm{Mg}$-Al mixed oxide catalysts.

Entry (\%)

Reaction conditions: alcohols (1 mmol), aniline $(2 \mathrm{mmol})$, catalyst $(0.3 \mathrm{~g})$, toluene $(10 \mathrm{~mL}), 80^{\circ} \mathrm{C}$, air $(0.1 \mathrm{MPa})$. 


\section{Graphical Abstract}

Chin. J. Catal., 2018, 39: 309-318 doi: 10.1016/S1872-2067(17)63006-7

Oxidative coupling of alcohols and amines to an imine over Mg-Al acid-base bifunctional oxide catalysts

Jinling Song, Guiyang Yu, Xi Li, Xuwei Yang, Wenxiang Zhang *, Wenfu Yan, Gang Liu *

Jilin University

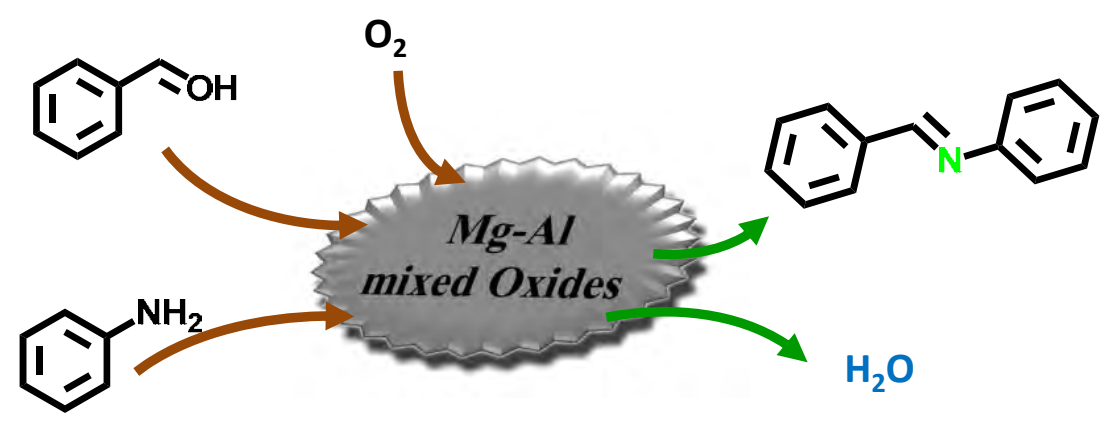

Mg-Al mixed oxides with acid-base bifunctional properties can effectively catalyze the aerobic coupling of alcohols and amines to imine.

hol activation, and the activation of benzyl alcohol is the rate-determining step for this oxidative coupling reaction. This work is very helpful to understand the role of the surface acid-base properties in the oxidative coupling reaction at low temperature, and will provide a new method for the development of irreducible acid-base catalysts for the imine synthesis.

\section{References}

[1] A. Mukherjee, A. Nerush, G. Leitus, L. J. W. Shimon, Y. B. David, N. A. E. Jalapa, D. Milstein, J. Am. Chem. Soc., 2016, 138, 4298-4301.

[2] S. Furukawa, A. Suga, T. Komatsu, Chem. Commun., 2014, 50, 3277-3280.

[3] M. Mastalir, M. Glatz, N. Gorgas, B. Stöger, E. Pittenauer, G. Allmaier, L. F. Veiros, K. Kirchner, Chem. Eur. J., 2016, 22, 12316-12320.

[4] Z. B. Han, Z. Wang, X. M. Zhang, K. L. Ding, Angew. Chem. Int. Ed., 2009, 48, 5345-5349.

[5] A. J. A. Watson, J. M. J. Williams, Science, 2010, 329, 635-636.

[6] S. Morales, F. G. Guijarro, J. L. García Ruano, M. B. Cid, J. Am. Chem. Soc., 2014, 136, 1082-1089.

[7] G. F. Liang, A. Q. Wang, L. Li, G. Xu, N. Yan, T. Zhang, Angew. Chem. Int. Ed., 2017, 56, 3050-3054.

[8] C. Izquierdo, F. Esteban, A. Parra, R. Alfaro, J. Alemán, A. Fraile, J. L. García Ruano, J. Org. Chem., 2014, 79, 10417-10433.

[9] B. Chen, L. Y. Wang, W. Dai, S. S. Shang, Y. Lü, S. Gao, ACS. Catal., 2015, 5, 2788-2794.

[10] M. Largeron, M. B. Fleury, Science, 2013, 339, 43-44.

[11] B. Chen, S. S. Shang, L. Y. Wang, Y. Zhang, S. Gao, Chem. Commun., 2016, 52, 481-484.

[12] G. J. Chen, H. C. Ma, W. L. Xin, X. B. Li, F. Z. Jin, J. S. Wang, M. Y. Liu, Y. B. Dong, Inorg. Chem., 2017, 56, 654-660.

[13] T. Yan, B. L. Feringa, K. Barta, Nat. Commun., 2014, 5, 5602-5609.

[14] L. Jiang, L. L. Jin, H. W. Tian, X. Q. Yuan, X. C. Yu, Q. Xu, Chem. Commun., 2011, 47, 10833-10835.

[15] W. He, L. D. Wang, C. L. Sun, K. K. Wu, S. B. He, J. P. Chen, P. Wu, Z. K.
Yu, Chem. Eur. J., 2011, 17, 13308-13317.

[16] R. Cano, D. J. Ramón, M. Yus, J. Org. Chem., 2011, 76, 5547-5557.

[17] H. Sun, F. Z. Su, J. Ni, Y. Cao, H. Y. He, K. N. Fan, Angew. Chem. Int. Ed., 2009, 48, 4390-4393.

[18] S. Kegnæs, J. Mielby, U. V. Mentzel, C. H. Christensen, A. Riisager, Green Chem., 2010, 12, 1437-1441.

[19] L. L. Zhang, W. T. Wang, A. Q. Wang, Y. T. Cui, X. F. Yang, Y. Q. Huang, X. Y. Liu, W. G. Liu, J. Y. Son, H. Oji, T. Zhang, Green Chem., 2013, 15, 2680-2684.

[20] P. Liu, C. Li, E. J. M. Hensen, Chem. Eur. J., 2012, 18, 12122-12129.

[21] B. Chen, J. Li, W. Dai, L. Y. Wang, S. Gao, Green Chem., 2014, 16, 3328-3334.

[22] L. L. Geng, B. Zheng, X. Wang, W. X. Zhang, S. J. Wu, M. J. Jia, W. F. Yan, G. Liu, ChemCatChem, 2016, 8, 805-811.

[23] M. Tamura, K. Tomishige, Angew. Chem. Int. Ed., 2015, 54, 864-867.

[24] Y. W. Xu, F Wang, S. J. Yu, X. W. Li, Chin. J. Catal., 2017, 38, 1390-1398.

[25] M. X. Zhou, L. L. Zhang, J. T. Miller, X. F. Yang, X. Y. Liu, A. Q. Wang, T. Zhang, Chin. J. Catal., 2016, 37, 1764-1770.

[26] L. L. Geng, J. L. Song, B. Zheng, S. J. Wu, W. X. Zhang, M. J. Jia, G. Liu, Chin J. Catal., 2016, 37, 1451-1460.

[27] L. L. Geng, J. L. Song, Y. H. Zhou, Y. Xie, J. H. Huang, W. X. Zhang, L. M. Peng, G. Liu, Chem. Commun., 2016, 52, 13495-13498.

[28] R. D. Patil, S. Adimurthy, Asian J. Org. Chem., 2013, 2, 726-744.

[29] B. Chen, L. Y. Wang, S. Gao, ACS. Catal, 2015, 5, 5851-5876.

[30] X. B. Huang, L. P. Liu, H. Y. Gao, W. J. Dong, M. Yang, G. Wang, Green Chem., 2017, 19, 769-777.

[31] M. Ciaccia, S. Pilati, R. Cacciapaglia, L. Mandolini, S. Di Stefano, Org. Biomol. Chem., 2014, 12, 3282-3287.

[32] M. E. Manríquez, T. López, R. Gómez, J. Navarrete, J. Mol. Catal. A, 2004, 220, 229-237.

[33] J. Lee, E. J. Jang, J. H. Kwak, J. Catal., 2017, 345, 135-148.

[34] J. Seth, D. Nepak, V. R. Chaudhari, B. L. V. Prasad, Appl. Surf. Sci., 2017, 418, 87-91.

[35] J. Z. Hu, S. C. Xu, J. H. Kwak, M. Y. Hu, C. Wan, Z. C. Zhao, J. Szanyi, X. 
H. Bao, X. W. Han, Y. Wang, C. H. F. Peden, J. Catal., 2016, 336, 85-93.

[36] C. Wan, M. Y. Hu, N. R. Jaegers, D. C. Shi, H. M. Wang, F. Gao, Z. H. Qin, Y. Wang, J. Z. Hu, J. Phys. Chem. C, 2016, 120, 23093-23103.

[37] I. Yanase, Y. Saito, H. Kobayashi, J. Therm. Anal. Calorim., 2017, 129, 1271-1276.

[38] L. A. O'Dell, S. L. P. Savin, A. V. Chadwick, M. E. Smith, Solid State Nucl. Magn. Reson., 2007, 31, 169-173.

[39] S. Shylesh, D. Kim, A. A. Gokhale, C. G. Canlas, J. O. Struppe, C. R. Ho, D. Jadhav, A. Yeh, A. T. Bell, Ind. Eng. Chem. Res., 2016, 55, 10635-10644.

[40] K. K. Ramasamy, M. Gray, H. Job, D. Santosa, X. H. S. Li, A. Devaraj, A. Karkamkar, Y. Wang, Top. Catal., 2016, 59, 46-54.

[41] O. Bergadà, I. Vicente, P. Salagre, Y. Cesteros, F. Medina, J. E. Sueiras, Microporous Mesoporous Mater., 2007, 101, 363-373.

[42] F. Prinetto, G. Ghiotti, P. Graffin, D. Tichit, Microporous Mesoporous Mater., 2000, 39, 229-247.
[43] V. K. Díez, C. R. Apesteguía, J. I. Di Cosimo, J. Catal., 2003, 215, 220-233.

[44] J. I. Di Cosimo, V. K. Díez, M. Xu, E. Iglesia, C. R. Apesteguía, J. Catal., 1998, 178, 499-510.

[45] J. I. Di Cosimo, C. R. Apesteguía, M. J. L. Ginés, E. Iglesia, J. Catal,, 2000, 190, 261-275.

[46] V. K. Díez, J. I. Di Cosimo, C. R. Apesteguía, Appl. Catal. A, 2008, 345, 143-151.

[47] L. Čapek, P. Kutálek, L. Smoláková, M. Hájek, I. Troppová, D. Kubička, Top. Catal., 2013, 56, 586-593.

[48] D. L. Carvalho, R. R. de Avillez, M. T. Rodrigues, L. E. P. Borges, L. G. Appel, Appl. Catal. A, 2012, 415-416, 96-100.

[49] A. L. McKenzie, C. T. Fishel, R. J. Davis, J. Catal., 1992, 138, 547-561.

[50] P. Liu, M. Derchi, E. J. M. Hensen, Appl. Catal. A, 2013, 467, 124-131.

\section{镁铝酸碱双功能氧化物催化剂上醇胺氧化耦合合成亚胺性能}

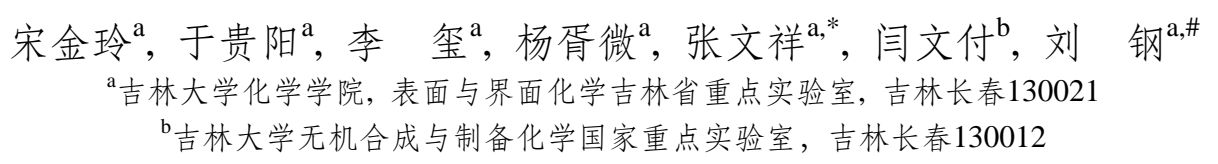

摘要: 亚胺是一类重要的含氮有机化合物, 由于具有不饱和 $\mathrm{C}=\mathrm{N}$ 双键, 可以作为一种有效的氮源, 用于一系列含氮衍生物 的合成. 目前合成亚胺的工艺路线主要是通过羰基化合物和一级胺在强酸条件下缩合; 与该路线相比, 醇和胺在空气或氧 气存在条件下耦合是一条更为绿色的工艺路线, 其副产物只有水产生. 目前的报道表明, 一些具有氧化还原性质的催化剂, 如负载型贵金属催化剂和负载型过渡金属氧化物催化剂在该反应中表现出一定催化性能, 但很少关注表面酸碱性质对该 反应性能的影响. 在本工作中, 我们尝试将具有酸碱双功能性质的Mg-Al复合氧化物作为催化剂用于该反应中, 考察了 $\mathrm{Mg} / \mathrm{Al}$ 比、焙烧温度和后处理条件对催化性能的影响. 结果显示, $\mathrm{Mg} / \mathrm{Al}=3$ 的催化剂在反应中表现出最优的催化活性; $\mathrm{NH}_{3}-\mathrm{TPD}$ 和 $\mathrm{CO}_{2}-\mathrm{TPD}$ 显示, 随着镁含量的增加, 样品表面碱性中心的数量呈现出先增加后减少的趋势, 其中 $\mathrm{Mg} / \mathrm{Al}=3$ 的样 品表面酸、碱总量最大, 而且该样品表面弱碱中心数量也最多; 我们通过焙烧和探针分子吸附等后处理手段进一步调控了 催化剂表面的酸碱性质, 初步结果表明在酸碱中心的协同作用下可以有效地催化醇和胺的氧化耦合反应; 其中弱碱性位 可能是活化醇的主要活性中心, 而醇的氧化是该反应的速控步骤, 因此可以推测表面弱碱中心的数量在一定程度上决定着 催化剂在该反应中的性能.

关键词: 氧化耦合; 亚胺合成; 醇氧化; 镁铝复合氧化物; 酸碱催化

收稿日期: 2017-11-13. 接受日期: 2017-12-25. 出版日期: 2018-02-05.

*通讯联系人. 电话: (0431)85155390; 传真: (0431)88499140; 电子邮箱: zhwenx@jlu.edu.cn

通讯联系人. 电话: (0431)85155390; 传真: (0431)88499140; 电子邮箱: lgang@jlu.edu.cn

基金来源：国家自然科学基金(21473073，21473074); 吉林省科技发展计划项目(20170101171JC); 吉林省教育厅“十三五”科学技 术研究项目(2016403); 国家重点实验室无机合成和制备化学的开放项目(201703).

本文的电子版全文由Elsevier出版社在ScienceDirect上出版(http://www.sciencedirect.com/science/journal/18722067). 